Title

\title{
Visual outcome of Anti-Vascular Endothelial Growth Factor Injections at the University College Hospital, Ibadan
}

T.S Oluleye ${ }^{1}$, Y.O Babalola, ${ }^{1}$ O Majekodunmi ${ }^{1}$, M Ijaduola, $^{1}$ A.T Adewole ${ }^{1}$

\section{Authors Information/Affiliations}

1. Tunji Sunday Oluleye - Consultant Ophthalmologist/Vitreo-Retinal Surgeon Institution ${ }^{1}$ : Department of Ophthalmology, University College Hospital, Ibadan. Nigeria.

2. Yewande Olubunmi Babalola ${ }^{1}$ - Consultant Ophthalmologist/Vitreo-Retinal Surgeon

3. Oluwole Majekodunmi ${ }^{I}$ - Consultant Ophthalmologist/Vitreo-Retinal Surgeon

4. Modupe Ijaduola ${ }^{-}$Consultant Ophthalmologist/Vitreo-Retinal Surgeon

5. Adeyemi Timothy, Adewole ${ }^{I}$-Ophthalmology Senior Registrar/Corresponding Author Email: Adeyemi.Adewole1@alumni.lshtm.ac.uk

Abstract:

Aim: To evaluate the four-year outcome of intravitreal anti-vascular endothelial growth factor (anti-VEGF) therapy in an eye unit in sub-Saharan Africa.

Methodology: This retrospective study included 182 eyes of 172 patients managed in the vitreoretinal unit between 2016 and 2019 who were treated with intravitreal anti-VEGF Bevacizumab $(1.25 \mathrm{mg} / 0.05 \mathrm{ml})$ with at least one year of follow up. The outcome measures were change in best-corrected visual acuity (BCVA) over one year of follow-up, the number of injections taken and complications.

Results: The mean age was $61.1 \pm 16.3$ years (M: F of 1:1.1) and about $62.1 \%$ were $\geq 60$ years. A total of 330 injections were given during the period audited. The mean number of injections was $1.8 \pm 0.93$. Ninety-four (51.7\%) eyes had only one injection while 33 (18.1\%), 50 (27.5\%) and 5 (2.7\%) had 2, 3 and 4 injections, respectively. About $78.5 \%$ had moderate-severe visual impairment at baseline and $44.5 \%, 16.4 \%, 12.6 \%$ and $7.1 \%$ at 1,3 , 6- and 12 months post injections, respectively. The mean BCVA improved for all eyes from $1.67 \pm 0.91 \log$ MAR at baseline to $1.50 \pm 1.27 \log$ MAR at one year. The $\log$ MAR letters gained was 23 at 1 month and 8.25 at 1 year with a statistically significant association between increasing number of injections and improved visual outcome $(\mathrm{p}=0.015)$. One patient each developed endophthalmitis $(0.6 \%)$ and inferior retinal detachment $(0.6 \%)$ post-injection.

Conclusion: Visual acuity gain was recorded in patients who had at least two intravitreal Anti-VEGF injections in 1 year.

Keywords: Intravitreal injections, bevacizumab (Avastin), ranibizumab (Lucentis), anti-VEGF, visual outcome 
medRxiv preprint doi: https://doi.org/10.1101/2020.06.16.20132662; this version posted June 19, 2020. The copyright holder for this preprint (which was not certified by peer review) is the author/funder, who has granted medRxiv a license to display the preprint in perpetuity.

It is made available under a CC-BY-NC-ND 4.0 International license .

\section{Introduction}

Vascular endothelial growth factor (VEGF) is stimulated in response to hypoxia in all vascularized intraocular tissue. The pathophysiologic mechanisms of most retinal diseases involve vascular proliferation and leakage in which VEGF is the main signal. ${ }^{1}$ Despite the complex pathophysiologic mechanisms of retinal damage in various intraocular vascular diseases, the use of anti-VEGF therapy is an effective therapeutic agent in various clinical trials for choroidal neovascular membrane from age-related macular degeneration (wet AMD), diabetic macular oedema (DME), macular oedema due to retinal vein occlusion (RVO), myopic choroidal neovascularisation (myopic CNV) and other retinal diseases. ${ }^{2}$

Anti-VEGF is also commonly used as standard therapy for various retinal vascular diseases, either as first or second-line treatment of choice. ${ }^{2,3,4,5}$ Although the use of Bevacizumab (Avastin) is off-label, it has been recommended as a cheaper non-inferior option to the other alternatives like Ranibizumab or Aflibercept. Similarly, bevacizumab is a preferred choice in low resource settings like ours, where patients in urgent need of anti-VEGF agents have to pay out of pocket. ${ }^{6}$

Various anti-VEGF treatment protocols have been advocated for the management of various retinal vascular diseases, with some dosing regimen supporting multiple injections. ${ }^{4,5,7}$ For instance, the "continuous dosing" regimen proposed by the MARINA study involves the use of monthly injections, while the PRONTO study offered "treatment as required" as guided by the OCT scan thus making patients require fewer injections unlike the MARINA study; but with similar visual outcome. ${ }^{8,9}$ Furthermore, the "treat and extend" regime aimed to reduce the treatment burden on patients by extending follow-up and/or treatment as determined by disease stability. ${ }^{2,10}$ The use of "initial 3 loading doses" followed by "as-needed treatment" showed excellent visual outcome in the $\mathrm{ABC}$ trial. ${ }^{11}$ Despite the cost-effectiveness of bevacizumab and 
medRxiv preprint doi: https://doi.org/10.1101/2020.06.16.20132662; this version posted June 19, 2020. The copyright holder for this preprint (which was not certified by peer review) is the author/funder, who has granted medRxiv a license to display the preprint in perpetuity.

It is made available under a CC-BY-NC-ND 4.0 International license .

proven treatment protocols recommending it to patients, the outcomes of the therapy have varied in the face of pervasive under treatment in low resource settings.

In this retrospective study, we seek to evaluate the 12-month visual outcome and relationship with the number of anti-VEGF injections in eyes with retinal vascular diseases to make recommendations for patients' care in our practice and other similar settings to our health system where the scourge of retinal diseases is progressively becoming burdensome. ${ }^{12,13}$

\section{Methodology}

In this retrospective study, medical records of patients who were treated with intravitreal bevacizumab at the University College Hospital, Ibadan, Nigeria from January 2016 to December 2019 were retrieved. This study adhered to the tenets of the Declaration of Helsinki. All patients consented to the Off-label use of bevacizumab. All procedures were carried out in the operating theatre under aseptic condition. The eye to be injected was prepared with $10 \%$ povidone-iodine to the periocular skin and lids, $5 \%$ povidone-iodine drops instilled into the conjunctiva sac, topical tetracaine was added before the povidone. Calliper measurements from the limbus were done to ensure injection was given through the pars plana (4mm for phakics and $3.5 \mathrm{~mm}$ for pseudophakics; $1.5 \mathrm{~mm}$ for neonates). Intravitreal injections $(1.25 \mathrm{mg} / 0.05 \mathrm{ml}$ for adults, $0.625 \mathrm{mg}$ for neonates) of bevacizumab (Avastin, Roche, Basel, Switzerland) or $0.5 \mathrm{mg} / 0.05 \mathrm{ml}$ for adults, $0.25 \mathrm{mg}$ for neonates for ranibizumab (Lucentis, Novartis, Basel, Switzerland) were used. The choice of using either bevacizumab or ranibizumab was based on affordability by the patient. All patients were given topical moxifloxacin qid for 1 week after each injection.

Also, all patients were scheduled to have treatment on as-needed basis after the initial monthly 3 loading dosage. Eligible patients were those who had at least one injection. Patients were reviewed first-day post- 
medRxiv preprint doi: https://doi.org/10.1101/2020.06.16.20132662; this version posted June 19, 2020. The copyright holder for this preprint (which was not certified by peer review) is the author/funder, who has granted medRxiv a license to display the preprint in perpetuity.

It is made available under a CC-BY-NC-ND 4.0 International license .

injection for signs of undue inflammation and raised intraocular pressure. Patients were then reviewed monthly. Visual acuity assessment and dilated fundus examination were done at every visit. Optical Coherence Tomography scan was requested when visual acuity deteriorated.

Data extracted from case notes include clinical characteristics of the patients such as age, sex, eye (s) injected, systemic comorbidities, number of injections and best-corrected visual acuity (BCVA). The outcome measures were the change in BCVA over one year of follow-up, the number of injections taken and any associated complication.

Data was analysed using the Statistical Package for Social Sciences (SPSS), version 24 (SPSS Inc., Chicago, Illinois, USA), and reported as frequency distributions, percentages, and means \pm standard deviation (SD). Snellen visual acuities were converted to logarithm of minimum angle of resolution $(\log \mathrm{MAR})$ for statistical analysis. BCVAs from the baseline, 1, 3, 6 and at 12 months were compared. Categorical variables were compared using $\chi^{2}$, and continuous variables were compared using the paired sample t-test. A $p<0.05$ was considered statistically significant.

\section{Results}

A total of 206 patients' medical records were requested but only $172(83.5 \%)$ were retrieved successfully. One hundred and eighty-two eyes of 172 patients who had injections were analysed with a follow-up of 12 months. The mean age was $61.1 \pm 16.3$ years ( 89 males, $\mathrm{M}$ : $\mathrm{F}$ of $1: 1.1)$ with about $62.1 \%$ being 60 years and above (table 1). The most common indication was retinal venous occlusion, 64 (35.2\%) followed by wet age-related macular degeneration, $42(23 \%)$.

About 78.5\% had moderate-severe visual impairment (MSVI) at baseline and 44.5\%, 16.4\%,12.6\% and $7.1 \%$ at 1, 3, 6 and 12months post injections respectively (Figure 1). A total of 330 injections were given 
medRxiv preprint doi: https://doi.org/10.1101/2020.06.16.20132662; this version posted June 19, 2020. The copyright holder for this preprint (which was not certified by peer review) is the author/funder, who has granted medRxiv a license to display the preprint in perpetuity.

It is made available under a CC-BY-NC-ND 4.0 International license .

with the mean number of injections of $1.8 \pm 0.93$. Ninety-four eyes, $94(51.7 \%)$ eyes had only one injection while $88(48.3 \%)$ had at least 2 injections.

The mean BCVA improved for all eyes from $1.67 \pm 0.91 \log$ MAR at baseline to $1.21 \pm 1.01 \log \mathrm{MAR}, 1.41$

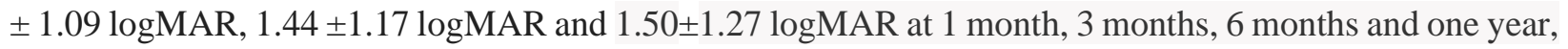
respectively. The logMAR letters gained progressively declined from 23 at 1 month to about 8 letters at 1 year (Figure 2). Patients who had at least 2 injections were significantly $(\mathrm{p}=0.015)$ more likely to have better visual outcome than those who had just one injection (table2). One patient each developed endophthalmitis $(0.6 \%)$ and inferior retinal detachment $(0.6 \%)$ post-injection. 
medRxiv preprint doi: https://doi.org/10.1101/2020.06.16.20132662; this version posted June 19, 2020. The copyright holder for this preprint (which was not certified by peer review) is the author/funder, who has granted medRxiv a license to display the preprint in perpetuity.

It is made available under a CC-BY-NC-ND 4.0 International license .

Table 1: Demographic and clinical characteristics of patients

\begin{tabular}{|c|c|c|}
\hline & Frequency $(\mathbf{n}=182)$ & Percentage $(\%)$ \\
\hline \multicolumn{3}{|l|}{ Age, mean $=61.1 \pm 16.3$} \\
\hline$\geq 60$ years & 113 & 62.1 \\
\hline $17-39$ years & 6 & 3.3 \\
\hline $40-59$ years & 57 & 31.3 \\
\hline 6-16 years & 2 & 1.1 \\
\hline Infant-5years & 4 & 2.2 \\
\hline \multicolumn{3}{|l|}{ Sex } \\
\hline Male & 89 & 48.9 \\
\hline Female & 93 & 51.1 \\
\hline \multicolumn{3}{|l|}{ Eye } \\
\hline Right Eye & 94 & 51.6 \\
\hline Left Eye & 88 & 48.4 \\
\hline \multicolumn{3}{|l|}{ Indications } \\
\hline Wet Age-related macular degeneration/CNVM & 42 & 23.0 \\
\hline CRVO & 34 & 18.7 \\
\hline PDR/DME & $27 * *$ & 14.8 \\
\hline IPCV & 18 & 9.9 \\
\hline HRVO & 16 & 8.9 \\
\hline BRVO & 14 & 7.7 \\
\hline CME & 9 & 4.9 \\
\hline SCR & 6 & 3.3 \\
\hline RAM & 4 & 2.2 \\
\hline ROP & 3 & 1.7 \\
\hline NVG & 2 & 1.0 \\
\hline Others & $7 * * *$ & 3.9 \\
\hline \multicolumn{3}{|l|}{ Baseline Snellen Visual Acuity (logMAR } \\
\hline $6 / 6(0.0)$ & 5 & 2.7 \\
\hline $6 / 9(0.2)$ & 4 & 2.2 \\
\hline $6 / 12(0.3)$ & 7 & 3.8 \\
\hline $6 / 18(0.5)$ & 16 & 8.8 \\
\hline $6 / 24(0.6)$ & 8 & 4.4 \\
\hline $6 / 36(0.8)$ & 17 & 9.3 \\
\hline $6 / 60(1.0)$ & 16 & 8.8 \\
\hline $\mathrm{CF}(2.3)$ & 77 & 42.3 \\
\hline HM (2.5) & 25 & 13.7 \\
\hline LP (3.0) & 2 & 1.1 \\
\hline $\operatorname{NLP}(4.0)$ & 2 & 1.1 \\
\hline
\end{tabular}


medRxiv preprint doi: https://doi.org/10.1101/2020.06.16.20132662; this version posted June 19, 2020. The copyright holder for this preprint (which was not certified by peer review) is the author/funder, who has granted medRxiv a license to display the preprint in perpetuity.

\section{It is made available under a CC-BY-NC-ND 4.0 International license .}

\begin{tabular}{|c|c|c|}
\hline & $\operatorname{Frequency}(\mathrm{n}=182)$ & Percentage $(\%)$ \\
\hline \multicolumn{3}{|l|}{ No of injections, mean $=1.8 \pm 0.93$} \\
\hline 1 & 94 & 51.7 \\
\hline 2 & 33 & 18.1 \\
\hline 3 & 50 & 27.5 \\
\hline 4 & 5 & 2.7 \\
\hline \multicolumn{3}{|l|}{ Type of Injection } \\
\hline Bevacizumab (Avastin) & 180 & 98.9 \\
\hline Ranibizumab (Lucentis) & 2 & 1.1 \\
\hline \multicolumn{3}{|l|}{ Complications } \\
\hline Endophthalmitis & 1 & 0.6 \\
\hline Retinal detachment $*$ & 1 & 0.6 \\
\hline
\end{tabular}

$\mathrm{CNVM}=$ choroidal neovascular membrane; $\mathrm{AMD}=$ age related macular degeneration; $\mathrm{CRVO}=$ central retinal vein occlusion; $\mathrm{PDR}=$ proliferative diabetic maculopathy; $\mathrm{DME}=$ diabetic macular oedema; IPCV= Idiopathic Polypoidal Choroidal Vasculopathy; $\mathrm{HRVO}=$ hemi-retinal vein occlusion: $\mathrm{BRVO}=$ branch Retinal Vein Occlusion; $\mathrm{CME}=$ cystoid macular oedema; $\mathrm{SCR}=$ sickle cell Retinopathy; RAM= retinal arterial macroaneurysm; ROP= retinopathy of prematurity; $\mathrm{NVG}=$ neovascular glaucoma

* 3 infants with Retinopathy of Prematurity had no objective assessment of visual acuity of documented ** one patient had severe non-proliferative diabetic retinopathy

***Vitreous haemorrhage in POAG, Presumed Toxoplasmosis, Choroidal melanoma, Intraretinal mass (unspecified), Haemorrhagic macular detachment, Specific uveitis and Myopic CNVM

* Inferior bullous developed post 3rd injection 
medRxiv preprint doi: https://doi.org/10.1101/2020.06.16.20132662; this version posted June 19, 2020. The copyright holder for this preprint (which was not certified by peer review) is the author/funder, who has granted medRxiv a license to display the preprint in perpetuity.

\section{It is made available under a CC-BY-NC-ND 4.0 International license .}

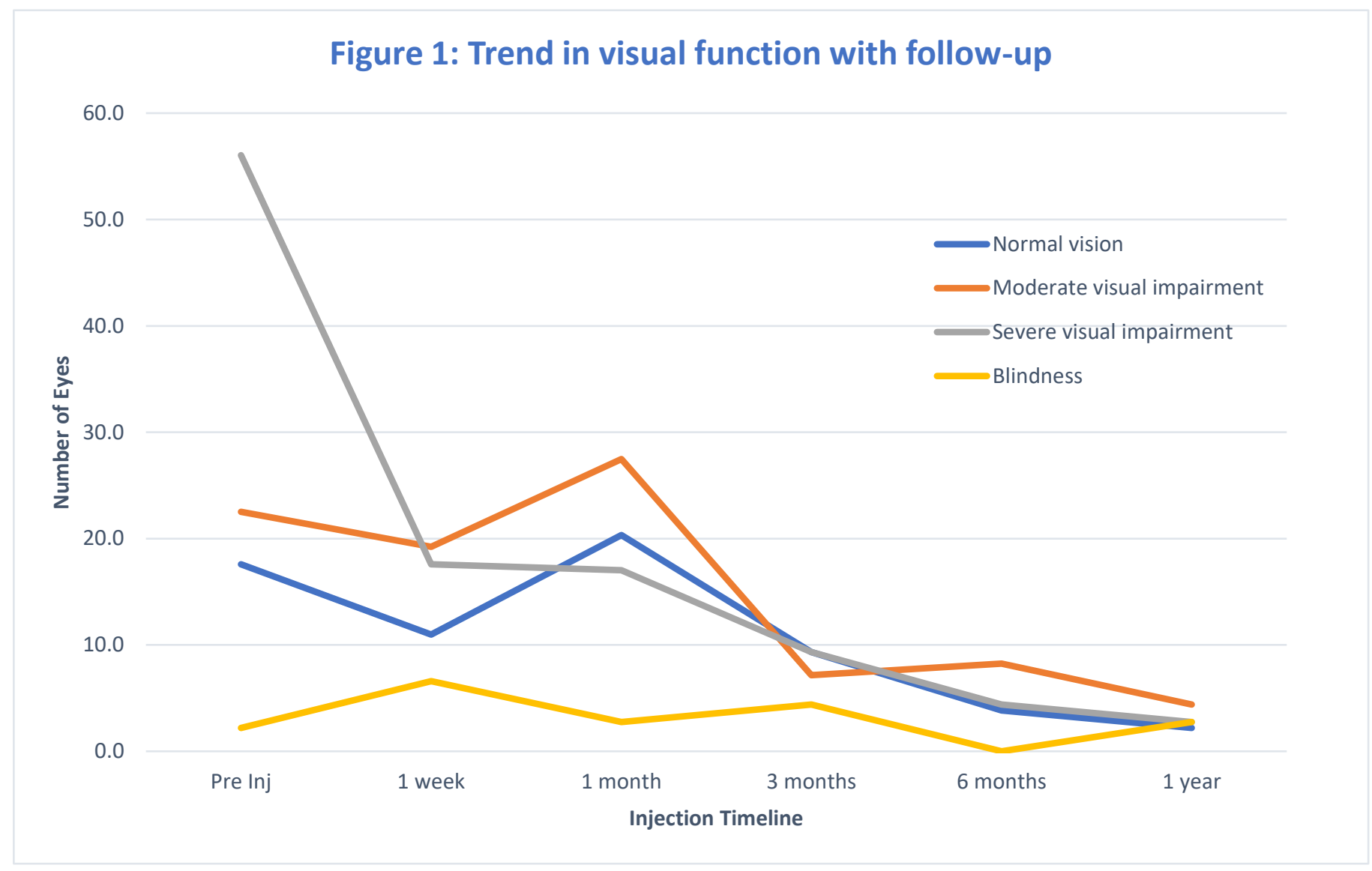


medRxiv preprint doi: https://doi.org/10.1101/2020.06.16.20132662; this version posted June 19, 2020. The copyright holder for this preprint (which was not certified by peer review) is the author/funder, who has granted medRxiv a license to display the preprint in perpetuity.

\section{It is made available under a CC-BY-NC-ND 4.0 International license .}

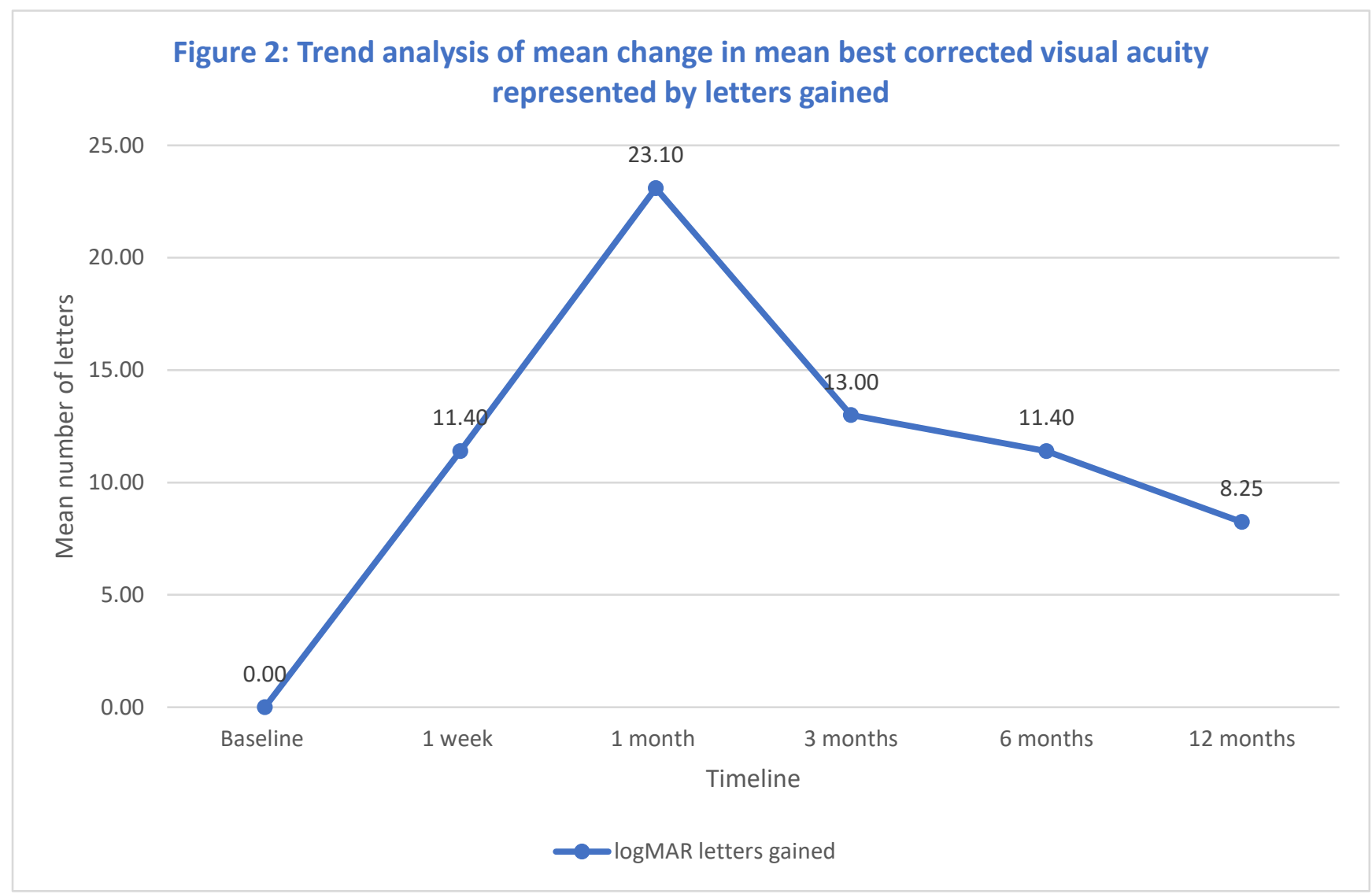


medRxiv preprint doi: https://doi.org/10.1101/2020.06.16.20132662; this version posted June 19, 2020. The copyright holder for this preprint (which was not certified by peer review) is the author/funder, who has granted medRxiv a license to display the preprint in perpetuity.

It is made available under a CC-BY-NC-ND 4.0 International license .

Table 2: Relationship between clinical characteristics and number of injections

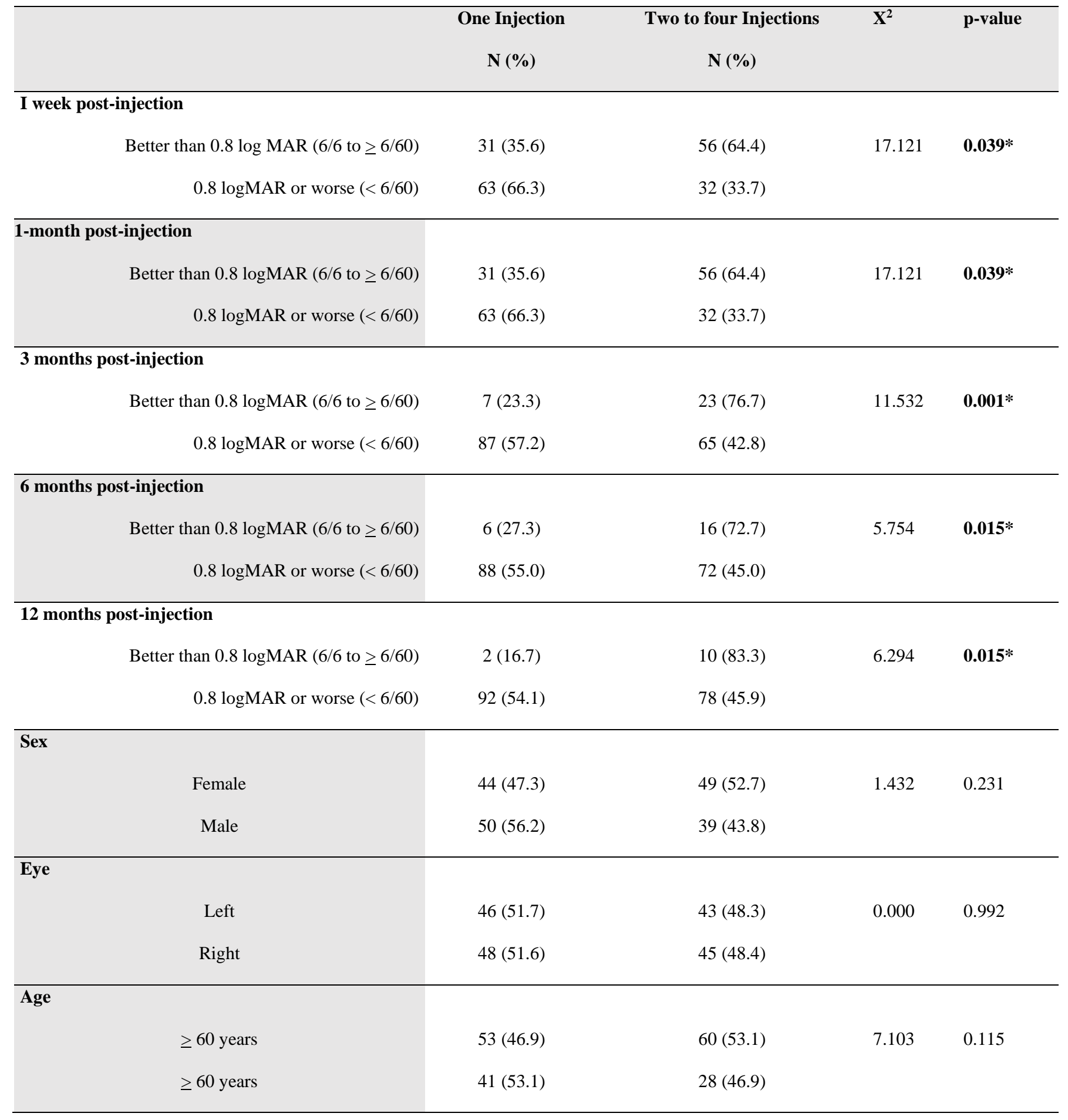

- $\quad$ * Statistically significant level $(\mathbf{p}<0.005)$ 
medRxiv preprint doi: https://doi.org/10.1101/2020.06.16.20132662; this version posted June 19, 2020. The copyright holder for this preprint (which was not certified by peer review) is the author/funder, who has granted medRxiv a license to display the preprint in perpetuity.

It is made available under a CC-BY-NC-ND 4.0 International license .

\section{Discussion}

The mean age of patients involved in this study is similar to that in other centres in Nigeria. ${ }^{14-17}$ But, the wide age range was due to the inclusion of babies who received anti-VEGF for retinopathy of prematurity.

Almost all our patients, 180 (98.9\%) had the less expensive bevacizumab injection, which is akin

to other studies done both locally. ${ }^{14-17}$ On the other hand, a report from the oil-rich setting of PortHarcourt in Nigeria reported about $25 \%$ usage of Ranibizumab. ${ }^{18}$ A vial of bevacizumab is shared (repackaged bevacizumab) by 10- 20 patients to further reduce the cost in a pooled funding system of the unit to encourage compliance with the treatment regime. Even though our patients had been counselled on the need to have the recommended monthly dose of 3 injections, only about $27.5 \%$ (50) complied to regimen and $51.7 \%$ (94) had only one injection due to financial constraints as they pay out of pocket. The average number of injections in this cohort $(1.8 \pm 0.9)$ is akin to a similar study reported in a tertiary hospital in Benin, ${ }^{16}$ but at variance with the higher mean number of injections reported in major landmark clinical trials that have shaped the preferred practice pattern for intravitreal anti-VEGF injections. ${ }^{2,8-10,12}$ A strong health system with an effective financial payment and insurance coverage could have been the reason for this disparity.

We found that this cohort had improved vision which was better in those that had at least two injections over the 12 months follow-up period. The average number of letters gained was highest at one-month postinjection but was not sustained as it declined to 13 and finally to 8.5 letters (1.7 lines) at 12-month but this improvement was still a statistically significant outcome. Uhumwangho ${ }^{16}$ similarly reported visual improvement in about $50 \%$ of studied patients. Pham et al, ${ }^{2}$ in their systematic review and meta-analysis reported varying levels of visual outcomes depending on the specific disease. Chin-Yee et al, ${ }^{4}$ systematic reviews reported a mean improvement in visual acuity of 5.4 and about 10 ETDRS letters in PRN and treat and extend regimens respectively and the average of 5.6 and 8 injections over 12 months for wet ARMD. 
medRxiv preprint doi: https://doi.org/10.1101/2020.06.16.20132662; this version posted June 19, 2020. The copyright holder for this preprint (which was not certified by peer review) is the author/funder, who has granted medRxiv a license to display the preprint in perpetuity.

It is made available under a CC-BY-NC-ND 4.0 International license .

Lai et $\mathrm{al}^{20}$ reported 14 letters (2.8 lines) improvement for myopic CNVM at 24 months. Conversely, Low et $a,^{7}$ stated that among the 17 trials reviewed, none of them stated any clinically significant visual improvement (> 5 letters) across the three major retinal vascular diseases scheduled for anti-VEGF injections (wet ARMD, DME and Central/Branch retinal vein occlusion irrespective of the type of antiVEGF agents used (bevacizumab, ranibizumab and aflibercept).

\section{Conclusion}

Our review has shown that the visual gain was more in those who had at least 2 injections. Therefore, it is recommended that anti-VEGF agents should be made available on the National Health Insurance Scheme, as well as enrolment of all citizens on the scheme. These acts will among other things, make anti-VEGF available and accessible to those that need it, thereby aiding to ease the various burdens associated in accessing these drugs.

Limitations: The study being a retrospective study, may be limited by accurate data retrieval from case records.

Contributions: I thank Mr. Iwa of the records department for the excellent work done in retrieving the case notes. Appreciation goes to Dr. Ibiyemi (Senior Registrar, Ophthalmology) and Mr. Seun Ayangbesan (Research assistant) who helped in data extraction. TO, YOB, OM, MI, and AA contributed to the design of the study and. AA analysed the data and prepared the initial manuscript. All authors reviewed, proofread, and approved the final manuscript and references. 
medRxiv preprint doi: https://doi.org/10.1101/2020.06.16.20132662; this version posted June 19, 2020. The copyright holder for this preprint (which was not certified by peer review) is the author/funder, who has granted medRxiv a license to display the preprint in perpetuity.

It is made available under a CC-BY-NC-ND 4.0 International license .

\section{References}

1. Miller JW, Le Couter J, Strauss EC, Ferrara N. Vascular endothelial growth factor a in intraocular vascular disease. Ophthalmology. 2013 Jan;120(1):106-14.

2. Pham B, Thomas SM, Lillie E, Lee T, Hamid J, Richter T, et al. Anti-vascular endothelial growth factor treatment for retinal conditions: A systematic review and meta-analysis. BMJ Open. 2019 May 1;9(5):e022031.

3. Calvo-Gonzalez C, Reche-Frutos J, Donate J, Fernandez-Perez C, Garcia-Feijoo J. Intravitreal ranibizumab for myopic choroidal neovascularization: Factors predictive of visual outcome and need for retreatment. Am J Ophthalmol. 2011 Mar 1;151(3):529-34.

4. Chin-Yee D, Eck T, Fowler S, Hardi A, Apte RS. A systematic review of as needed versus treat and extend ranibizumab or bevacizumab treatment regimens for neovascular age-related macular degeneration. Vol. 100, British Journal of Ophthalmology. BMJ Publishing Group; 2016. p. 914-7.

5. Haller JA. Current anti-vascular endothelial growth factor dosing regimens: Benefits and burden. Ophthalmology. 2013 May 1;120(5 SUPPL.): S3.

6. Hutton D, Newman-Casey PA, Tavag M, Zacks D, Stein J. Switching to less expensive blindness drug could save medicare part B \$18 billion over a ten-year period. Health Aff. 2014;33(6):931-9.

7. Low A, Faridi A, Bhavsar K V., Cockerham GC, Freeman M, Fu R, et al. Comparative effectiveness and harms of intravitreal antivascular endothelial growth factor agents for three retinal conditions: A systematic review and meta-analysis. Vol. 103, British Journal of Ophthalmology. BMJ Publishing Group; 2019. p. 442-51.

8. Lalwani GA, Rosenfeld PJ, Fung AE, Dubovy SR, Michels S, Feuer W, et al. A Variable-dosing Regimen with Intravitreal Ranibizumab for Neovascular Age-related Macular Degeneration: Year 
medRxiv preprint doi: https://doi.org/10.1101/2020.06.16.20132662; this version posted June 19, 2020. The copyright holder for this preprint (which was not certified by peer review) is the author/funder, who has granted medRxiv a license to display the preprint in perpetuity.

It is made available under a CC-BY-NC-ND 4.0 International license .

2 of the PrONTO Study. Am J Ophthalmol. 2009 Jul 1;148(1):43-58.e1.

9. Bressler NM, Chang TS, Suñer IJ, Fine JT, Dolan CM, Ward J, et al. Vision-Related Function after Ranibizumab Treatment by Better- or Worse-Seeing Eye. Clinical Trial Results from MARINA and ANCHOR. Ophthalmology. 2010 Apr 1;117(4):747-756.e4.

10. Khanna S, Komati R, Eichenbaum DA, Hariprasad I, Ciulla TA, Hariprasad SM. Current and upcoming anti-VEGF therapies and dosing strategies for the treatment of neovascular AMD: A comparative review. Vol. 4, BMJ Open Ophthalmology. BMJ Publishing Group; 2019. p. e000398.

11. Tufail A, Patel PJ, Egan C, Hykin P, Da Cruz L, Gregor Z, et al. Bevacizumab for neovascular agerelated macular degeneration (ABC Trial): Multicentre randomised double-masked study. BMJ. 2010 Jun 26;340(7761):1398.

12. Oluleye TS, Ajaiyeoba AI. Retinal diseases in Ibadan [69]. Vol. 20, Eye. Nature Publishing Group; 2006. p. 1461-3.

13. Oluleye TS, Babalola Y. Indications for Intravitreal Bevacizumab in Ibadan, Sub-Saharan Africa. Open Ophthalmol J. 2014 Dec 4;8(1):87-90.

14. Adenekan AO, Rotimi-Samuel A, Oluleye TS, Ilo OT, Musa KO, Amusan OO. Indications for intravitreal injections in Lagos University Teaching Hospital, Lagos, Nigeria. Nig Q J Hosp Med. 2017;27(2):765-7.

15. Bogunjoko TJ, Hassan A, Oderinlo O, Ogugua O, Ulaikere M, Akanbi T, et al. A Review of the Use of Anti-vascular Endothelial Growth Factor Drugs at the Eye Foundation Centre for the Prevention of Blindness, Nigeria. J Adv Med Med Res. 2018 Jul 3;1-7.

16. Uhumwangho O. Indications and treatment outcomes of intravitreal bevacizumab and ranibizumab for retinal diseases in Benin City, Nigeria. Niger J Ophthalmol. 2017;25(1):14. 
medRxiv preprint doi: https://doi.org/10.1101/2020.06.16.20132662; this version posted June 19, 2020. The copyright holder for this preprint (which was not certified by peer review) is the author/funder, who has granted medRxiv a license to display the preprint in perpetuity. It is made available under a CC-BY-NC-ND 4.0 International license .

17. Hassan S, Shuaib A. Indications for intravitreal anti-vascular endothelial growth factor in Kano, North-Western, Nigeria. Int J Res Med Sci Shuaib A al Int J Res Med Sci. 2016;4(7):2533-5.

18. Fiebai B, Odogu V. Intravitreal Anti Vascular Endothelial Growth Factor Agents in The Management of Retinal Diseases: An Audit. Open Ophthalmol J. 2017 Nov 7;11(1):315-21.

19. Holz FG, Amoaku W, Donate J, Guymer RH, Kellner U, Schlingemann RO, et al. Safety and efficacy of a flexible dosing regimen of ranibizumab in neovascular age-related macular degeneration: The SUSTAIN study. Ophthalmology. 2011 Apr;118(4):663-71.

20. Lai TYY, Luk FOJ, Lee GKY, Lam DSC. Long-term outcome of intravitreal anti-vascular endothelial growth factor therapy with bevacizumab or ranibizumab as primary treatment for subfoveal myopic choroidal neovascularization. Eye. 2012 May 18;26(7):1004-11. 